\title{
TEMPORARY EMPLOYMENT SERVICES: CLOSING A LOOPHOLE IN SECTION 198 OF THE LABOUR RELATIONS ACT 66 OF 1995*
}

\author{
Ezette Gericke \\ LLB LLM \\ Lecturer, Department of Mercantile Law \\ University of Pretoria
}

\begin{abstract}
SUMMARY
Section 198 of the Labour Relations Act (hereinafter "LRA") regulates the employment relationship between a worker (the employee), a labour broker (the employer) and a third party (the client). It also regulates the aspect of liability between the temporary employment service and its client on the one hand in relation to the employee/worker on the other hand. It is with regard to the latter aspect that the employee is in a detrimental position as far as the loss of protection against an unfair dismissal as regulated by sections 185 and 186 of the LRA is concerned.

The complexity of this kind of relationship is illustrated by means of a case study relating to an unfair dismissal dispute. Legislation regulating the employee's rights and the employer's duties upon termination of the contract of employment is also discussed. In conclusion, solutions and recommendations are offered to address the existing areas of concern with regard to section 198(4) and the client's responsibilities, the interpretation problems within the tripartite employment relationship, as well as the employment contract.
\end{abstract}

\section{INTRODUCTION}

This article deals with the problem of identifying the employer within the tripartite employment relationship that governs temporary employment services (hereinafter "TES"). It reflects briefly on the historical background and legal developments concerning a TES, and explores the question whether the Labour Relations Act $^{\dagger}$ has facilitated externalisation as a process whereby employers transform work previously done by employees into tripartite relationships between workers, clients and a labour broker or a TES. The trends and advantages of a TES as well as the International Labour Organisation (hereinafter "ILO") Recommendation 181 of 1997 are discussed. Section 198 of the LRA regulates the employment relationship between a worker (the employee), a labour broker (the employer) and a third

This article was presented at the Law Teachers Conference in July 2009 at the University of KwaZulu-Natal.

66 of 1995 (hereinafter "the LRA"). 
party (the client). It also regulates the aspect of liability between the TES and its client on the one hand in relation to the employee/worker on the other hand. It is with regard to the latter aspect that the employee is in a detrimental position as far as the loss of protection against an unfair dismissal as regulated by sections 185 and 186 of the LRA is concerned. The question of the employment relationship as a legal fiction is discussed. The client as the third party and the TES as the employer can only be held jointly and severally liable in terms of section 198(4) of the LRA "if the temporary employment service, in respect of any of its employees" (author's emphasis) contravenes the Basic Conditions of Employment Act, ${ }^{2}$ the Wage $\mathrm{Act}^{3}$ or a binding arbitration award regulating the terms and conditions of a contract of employment or a collective agreement.

The complexity of this kind of relationship is illustrated by means of a case study relating to an unfair dismissal dispute in LAD Brokers (Pty) Ltd $v$ Mandla. ${ }^{4}$ Legislation regulating the employee's rights and the employer's duties upon termination of the contract of employment is also discussed.

In conclusion, solutions and recommendations are offered to address the existing areas of concern with regard to section 198(4) and the client's responsibilities, the interpretation problems within the tripartite employment relationship, as well as the employment contract.

\section{HISTORICAL BACKGROUND OF THE TEMPORARY WORKER}

Under the previous South African regime labour relations were before 1980 regulated by labour legislation which excluded the African worker from the definition of an employee. ${ }^{5}$ The definition of an employee constitutes the crucial starting point whereby a worker would be afforded protection under labour legislation. ${ }^{6}$ The exclusion of migrant African workers, forming the majority of temporary workers in most sectors at the time, was of significant importance as they were employed in terms of fixed-term contracts.

Today labour brokers use the same legal mechanism to control the employment of temporary workers (employees of the broker) who are placed with a client. ${ }^{8}$ Although the drafters of the 1983 amendments seemed to have been wary of the extraordinary position of a broker "deemed" to be the

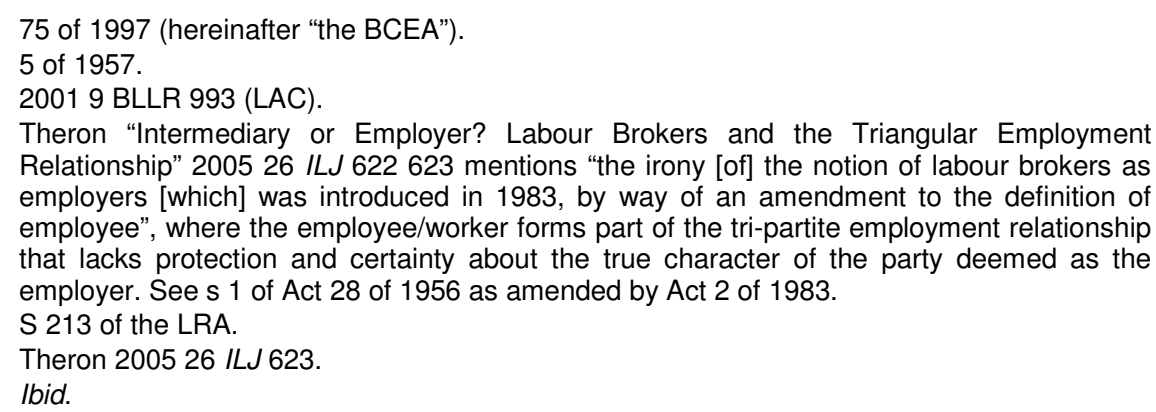


employer and of the fixed-term worker "deemed" as the employee, the 1995 LRA showed enough confidence in the position of the parties and the existence of this unusual employment relationship as the word "deemed" was phased out of the section.

This article therefore focuses on the so-called "employment relationship" which entails the liability of the employer (the TES or labour broker) in the event of an unfair dismissal, and that of the client who exercises control over the employee in the workplace. ${ }^{10}$ Labour legislation expressly excluded this kind of liability although reference is made to the TES and the client's joint liability in respect of the TES's breach of a collective agreement regulating a contract of employment or the BCEA. ${ }^{11}$

There has been a rapid growth in the establishment of and services provided by labour brokers since the 1983 LRA amendment and the regulation of labour brokers by section 198 by the LRA of $1995 .^{12}$ The period 1993 to 2002 marked a time of "exponential growth" in the existence of the TES. ${ }^{13}$ Although "it would never be possible to prove a causal relationship between an upsurge of labour-broking and labour legislation it is commonly suggested that labour legislation in South Africa has been instrumental in creating a rigid and inflexible labour market". ${ }^{14}$ The opposite is also believed to be true, as is illustrated by the increase in the numbers of TESs in the labour market. ${ }^{15}$ Employees of a TES have been marginalised from the protection of the LRA to a position which has been described by Theron as the "underclass in the workforce". ${ }^{16}$ This is in direct contrast with the allinclusive purpose and objects of the LRA which aims to advance the avoidance all forms of unfair discrimination in the workplace. ${ }^{17}$

Finally, section 23(1) of the Constitution of South Africa, 1996 guarantees a fundamental right in respect of labour relations by stating that "[e]veryone has the right to fair labour practices". ${ }^{18}$ This would naturally include the employee within the tripartite relationship of a TES as "everyone" involved in

See s 198(2) of the LRA 66 of 1995 and the discussion by Theron 200526 ILJ 623.

10 S 200A of the LRA and S 83A of the BCEA present seven factors related to the rebuttable presumption of people who earn less than R149 736 and who claim to fall within the protection afforded by the definition of an employee in s 213 of the LRA although they work within the parameters of "atypical" employment. If any one of the factors is present, regardless of the form of the contract, the presumption might apply. See Theron "The Shift to Services and Triangular Employment" 200829 ILJ 18.

1 See $s$ 198(4)(a)(c). Furthermore liability refers to a contravention of an arbitration award in ss (b) and of a determination in terms of the Wage Act 5 of 1957 in ss (d).

12 See Theron 200526 ILJ 625626.

13 Ibid.

14 See Theron 200526 ILJ 622626.

15 See Theron 200526 ILJ 622.

6 Ibid.

$\mathrm{S} 1(\mathrm{a})-(\mathrm{d})$ of the LRA.

18 S 23(1)-(6) of Constitution 1996, where the concept of "worker" has been extended to include even those engaged in atypical employment. 
employment in the workplace is afforded the protection of labour rights and fairness in terms of the Constitution. ${ }^{19}$

\section{HAS THE LABOUR RELATIONS ACT FACILITATED EXTERNALISATION?}

"Externalisation" is commonly understood as a process used by employers to transform and delegate work formerly done by permanent employees, to temporary workers at the workplace who are engaged in a tripartite relationship between the worker(s), the client and the labour broker. ${ }^{20}$

The legal mechanism which facilitates the relationship between the TES and the worker is the contract of employment (locatio conductio operarum). ${ }^{21}$ This needs to be distinguished from related contracts in terms of which services are rendered, namely, the contracts of agency, mandate and the contract for services (work) or the locatio conductio operis. ${ }^{22}$ The latter is an example of a contract concluded between the TES and the client in terms of which the services of a worker (employee of the TES) are placed under the authority and at the disposal of the client whilst the worker is remunerated by the TES. ${ }^{23}$

According to research done by Jan Theron, as well as information gathered by the Department of Labour (DoL) Survey of 2004, the above question regarding the role of the LRA in the facilitation of externalisation can be answered in the affirmative. ${ }^{24}$ The advantages of a TES being involved in the hiring of workers for employers (clients) by means of externalisation, can be linked to the following matters:

1 Section 198 of the LRA has created an attractive loophole for employers who opted to become clients of a TES within the tripartite relationship and who wish to avoid employment risks and the high costs of unfair dismissal proceedings. ${ }^{25}$

19 See s 1 of the Labour Relations Amendment Act 1991; Van Jaarsveld, Fourie and Olivier Principles and Practice of Labour Law (Loose leaf) (2009) par 67 and 68.

20 Van Niekerk Law@Work (2008) 65. See Theron 200829 ILJ 8, 11 and 12 where it is claimed that an estimated $300000-400000$ persons are connected to some form of TES "on any one day" as a result of externalisation in the service sector. No reliable data exist to indicate the number of people employed in the manufacturing, mining and agriculture sectors.

21 S 198(2) of the LRA.

22 Van Jaarsveld et al par 859. See s 198(3) of the LRA with regard to the position of the independent contractor being excluded from the definition of "employee" and the protection afforded by the LRA.

23 Van Niekerk 71. See s 198(1)(a) and (b) of the LRA.

24 Theron 200526 ILJ 625. Theron is a practising attorney, UCT researcher and director of the Institute of Development and Labour.

25 Ibid. See LAD Brokers (Pty) Ltd v Mandla supra 996, where the cancellation of the contract between the TES and the client resulted in a dismissal by the employer (TES) and unemployment for the employee. At 994 the court stated that it is the "clear intention" of the legislator to hold the employer (TES) liable as he remunerates the employee. The matter of dismissal becomes problematic when a client takes the first step to terminate his contract 
2 The reduction of labour costs and the enhancement of flexibility linked to uncertainty and competition in the business environment add to the advantages of entering into an agreement with a TES. ${ }^{26}$

3 Utilising a TES furthermore creates the opportunity to gain access to workers with specialised skills for a short period, according to the needs of the business and at a fraction of the cost of a permanent employment. $^{27}$

4 The LRA of 1995 has scrapped the requirement of registration for the TES industry. ${ }^{28}$ Section 24 of the Skills Development $A$ ct $^{29}$ provides that "any person who wishes to provide employment services for gain must apply for registration" (author's emphasis) but the Act nowhere refers to a TES as such a person. The purpose of registration seems to focus on the regulation of fees charged to work seekers by "such persons" rather than the regulation of relevant employment practices. ${ }^{30}$

5 As regards complying with any relevant collective agreement mentioned in "a discreet section of the LRA", Theron remarks that "a strong system of centralised bargaining failed to materialise. In these circumstances the other provisions regarding labour-broking ... became an open invitation to employers to escape [their] own prescriptions" with regard to the collective agreements to which they would have been bound.

6 Wage levels can be reduced for lesser-skilled workers as there is no requirement to ensure that workers placed by a TES receive the same level of remuneration than permanent workers of the client for similar work. ${ }^{32}$

7 Workers hired by a TES are in a vulnerable position as individuals in respect of negotiations as they are seldom in a position to negotiate for better working conditions or more favourable terms in their contract of employment with a TES. ${ }^{33}$

with the TES as this results in the dismissal of the worker by the TES as the employer. It is, however, clear that the "working relationship" between the worker and the client creates confusion to the extent that it is the client who instructs, supervises and sets the terms and conditions of employment, without a proper consultation as required by $s 198$ the LRA and not the TES as the statutory employer. See the presumptions in fn 10 above.

26 Hutchinson and Le Roux "Temporary Employment Services and the LRA: Labour Brokers, their Clients and the Dismissal of Employees" 20009 CLL 51.

Hutchinson and Le Roux 20009 CLL 52.

Theron 200526 ILJ 624.

97 of 1998 (hereinafter "SDA").

Theron 200526 ILJ 625.

Ibid. See s 198(4) of the LRA.

Theron 200526 ILJ 626629.

33 In the Mandla case supra 965 the worker was interviewed and accepted by the client before he was employed by the labour broker who then had to facilitate the contract of employment, and the remuneration of the worker for a fee. The worker was only expected to sign the contract with the broker and told that he would be working as an independent contractor, which means exclusion from the protection under the definition of employee in terms of the LRA (s 213). 


\section{TRENDS AND ADVANTAGES OF THE TEMPORARY EMPLOYMENT SERVICE SYSTEM IN SOUTH AFRICA}

Although workers face the possibility of being exploited either by the TES or the client of the TES, it is still a better option from an unemployed person's perspective to be part of a tripartite employment relationship than to face a day without the possibility of earning an income. ${ }^{34}$ Every person needs an opportunity to earn a living and add dignity to his or her her life. The development of a person's skills and abilities contributes to the physical and mental well-being of that person and his or her dependants. Social recognition and human dignity are values closely linked to a person's perception of worth and self-worth. ${ }^{35}$ It is in this regard that a labour broker or a TES has an extremely valuable role to play. Every society needs a system that is responsible for the creation of jobs and has the development of skills as its highest priority. ${ }^{36}$

It is official that South Africa, as most developing and developed countries currently do, is experiencing an economic recession. Retrenchments are on the cards for employees of many companies worldwide. In this regard TES fulfils a major role in ensuring bread on the table for millions. ${ }^{37}$ In response to a rapidly changing labour market, employers are forced to turn to a more flexible option than permanent employment. ${ }^{38}$ Industries using labour

34 Hutchinson and Le Roux 20009 CLL 51 and 53.

35 In Minister of Home Affairs $v$ Watchenuka 20044 SA 326 (SCA) par 27 the SCA accepted that "[t]he freedom to engage in productive work ... is indeed an important component of human dignity ... Self-esteem and the sense of self-worth - the fulfilment of what is to be human - is most often bound up with being accepted as socially useful". In Affordable Medicines Trust $v$ Minister of Health [2005] ZACC 3 (CC) par 59 the Constitutional Court noted that "one's work is part of one's identity and is constitutive of one's dignity" and that "there is a relationship between work and the human personality as a whole".

36 According to a Weekend Witness report of 4 May 2009 president Jacob Zuma announced that the ANC government will introduce laws to protect workers against exploitation, to "ensure decent work for all workers" and to "protect the employment relationship". The regulation of contract work, sub-contracting and outsourcing needs to be addressed to ensure the fundamental rights of workers who have "worked for decades without any security". Cosatu on the other hand strongly opposes labour-broking, outsourcing and casualisation of work and is in favour of "outlawing" this "exploitive labour practice which is another form of human trafficking", according to Cosatu's parliamentary co-ordinator, Prakashne Govender in The Herald of 6 May 2009. Source Legal Brief TODAY.

37 According to Richard Pike, CEO of Adcorp Holdings "the amount of job losses would be so high that it will make the number of the economic recession retrenchments 'insignificant' as employment services industry contributes billions of rand to the domestic economy, outperforming the agricultural sector". Mr Pike claims that "the industry abides by labour laws from the International Labour Organisation and the guidelines of its mother body, the Confederation of Associations in the Private Sector". According to him, Namibia banned labour-broking which resulted in $30 \%$ of all contractors losing their jobs: report from the Sowetan 21 May 2009 as stated in the Legal Brief TODAY.

38 The Confederation of Associations in the Private Employment Sector (Capes) comments on the restriction of flexible labour and confirms the "growing use [thereof as] an international trend" which contributes to prevent a "rigid labour force in an increasingly competitive global market" CEO John Botha Financial Mail 2 November 2007. 
brokers vary from mining, retail, engineering, clothing, fishing, farming and banking to the offices of SARS. The size of labour-broking companies in South Africa ranges from large companies such as Adcorp and Logical Options, which recruit and place thousands of employees in temporary employment to the "one-man bakkie-brigade" operators who aim for the daily destitute roadside job-seekers. ${ }^{39}$ It is estimated that "presently more than $30 \%$ of working South Africans earn their livelihood through work that can be described as informal". 40

The question regarding the relevant labour legislation to address and regulate the temporary employment service was discussed during $2003 .{ }^{41}$ Three years later in 2006 it was stated that "labour minister Membathisi Madladlana is in no hurry to amend labour laws, even though the cabinet deadline for a decision is long past". ${ }^{2}$ The issue under the presidency of $\mathrm{Mr}$ Zuma in 2009 is under severe pressure and the need for reform, especially of section 198 of the LRA, is a matter requiring an urgent solution. President Zuma expressed the undertaking of the ANC government to introduce laws to protect the employment relationship and workers as the weaker bargaining party from being exploited during contract work, outsourcing and sub-contracting. ${ }^{43}$

\section{IS EXISTING LABOUR AND OTHER RELATED LEGISLATION STILL RELEVANT AND EFFICIENT WITH REGARD TO THE PROTECTION OF THE RIGHTS OF WORKERS ENGAGED IN A TES?}

Although workers have better rights in 2009 than 15 years ago before the promulgation of the LRA of 1995 and the final Constitution, individuals choose to waive these rights when given the opportunity of a lifeline and the prospect of employment. Some contracts between the worker and the TES contain a clause permitting the TES to terminate the contract (dismissing the worker) because the client no longer needs the worker in his employment. ${ }^{44}$ This is an example of how intricate the cords are woven between the

39 "Labour brokers" 26 August 2005 Financial Mail.

40 Benjamin "Informal Work and Labour Rights in South Africa" 200829 ILJ 1579.

41 The labour department has no record of the number of labour brokers and the number of their employees as the clause requiring labour brokers to register, has been left out. According to Jan Theron, director of the Institute of Development \& Labour Law at the University of Cape Town, "the movement to this form of employment has been extreme [due to inter alia] labour market flexibility issues and the high costs of dispute resolution". See "Labour brokers" 3 October 2003 Financial Mail.

42 "Labour Regulation Dragging Out the Day" 18 May 2006 Financial Mail.

43 Weekend Witness fn 36 supra.

44 Bosch "Contract as a Barrier to Dismissal" 200829 ILJ 814. See April and Workforce Group Holdings (Pty) Ltd t/a the Workforce Group 200526 ILJ 2224 (CCMA), where it was held that a claim for unfair dismissal was unsuccessful because the worker failed to establish an unfair dismissal in terms of $\mathbf{s} 186$ of the LRA. The contractual terms had been considered in view of being contrary to public policy but not in terms of the values and role of the Constitution. 
common-law protection of the freedom and sanctity of contract and the fundamental rights protected by means of labour legislation. ${ }^{45}$

The TES or a labour broker is regulated by section 198 of the LRA. ${ }^{46}$ The Act refers to a TES as "any person who, for reward, procures for or provides to a client other persons who render services to, or perform work for, the client". That person is also remunerated by the TES. ${ }^{47}$ Section 198(2) confirms the existence of an employment agreement between the employee and the TES, which forms the foundation of the employment relationship. An employee is therefore a person who provides his or her services to a client by means of an agreement between the client and a TES, hence the reference to this interrelated relationship as being tripartite. Two agreements are linked in this relationship, that of the employment relationship between the TES and the worker on the one hand and a commercial agreement between the TES and the client requesting services to be rendered by the "employee" of the TES without an agreement between the worker and the client. $^{48}$ The independent contractor is excluded from the employment relationship and is therefore neither an employee of the TES nor can such a person enter into any employment agreement with the client of the TES. ${ }^{49}$

The liability of the TES and/or the client of that TES (as the employer), which is excluded from the employment relationship with the worker in whose service the latter renders a service, forms the crux of the current debate about the banning of TESs as requested by COSATU. The issue regarding present labour legislation regulating the TES in South Africa, is how it should be amended to protect the rights of temporary workers and prevent abuse by some of the TESs in the labour broker industry. ${ }^{50}$ The Act provides that the TES and the client are jointly and severally liable only if they are in contravention of the BCEA, arbitration awards, collective agreements and the Wage Act. ${ }^{51}$

In addition to the above-mentioned Acts, section 82 of the BCEA regulates the scope of the joint and several liability regarding salary

\footnotetext{
Bosch 200829 ILJ 814.

66 of 1995.

$S$ 198(1) of the LRA.

S 198(2) of the LRA. In services where a significant number of workers are employed by means of a fixed-term contract the tri-partite relationship serves the interests of the client as the dominant economical party. This reflects an economic vulnerability which ought to be addressed by means of the entrenched right to collective bargaining in $s 23$ of the Constitution. See Theron 200829 ILJ 16.

49 S 198(3) of the LRA. See Madlanya and Forster 199920 ILJ 2188 (ARB) where the arbitrator concluded that the "independent contractor agreement" was "a subterfuge" to avoid the responsibilities and obligations of the employer in terms of a collective agreement and refused tot give effect to it. See Hutchinson and Le Roux 20009 CLL 56.

50 S 198(4) of the LRA; according to an interview with Theron, employees waive their basic rights such as leave pay, sick pay, retrenchment or notice to accept the contractual terms of a TES, which complies with the requests of the client who then transfer his accountability to the broker. These illegal contracts and unscrupulous business dealings of the parties are seldom challenged in the Labour Court or during dispute settlements to the detriment of workers being treated as pawns. 3 October 2003 Financial Mail.

51 S 198(4) of the LRA.
} 
shortfalls, overtime disputes and/or incorrect working hours. ${ }^{52}$ The legislator attempted to address the issue of the disguised employment relationship and the true "employer's" liability regarding the temporary employee's rights to a degree of greater fairness and equity in section $57 .{ }^{53}$ If an employee of a TES renders a service to a client for a minimum period of three months, or for an indefinite period, that particular client shall be deemed to be the employer of that employee in terms of an unfair labour practice by that specific client. Both the TES and the client remain jointly and severally liable. ${ }^{54}$

SARS made provision for labour brokers to avoid practices which aim to "artificially disguise the employer-employee relationship" due to an overlap in the provisions of the amendments ${ }^{55}$ to the Income Tax Act ${ }^{56}$ in terms of which entities may request exemption certificates from SARS ${ }^{57}$ In terms of the revised Draft Interpretation Note No 35 which incorporates the said amendments, "any close corporation or trust that fits the definition of a personal service provider and which is in receipt of remuneration as defined in the Fourth Schedule to the Act, is subject to the deduction of employees' tax". ${ }^{58}$ In addition positive changes effected by the Revenue Laws Amendment Act, 2008 have been implemented in the Income Tax Act. ${ }^{59}$ Before 1 March 12009 amounts paid to a company (acting as a labour broker and personal service entity) by the client of that company for service rendered by an employee of the broker company, could be taxed as employee's tax (PAYE) ${ }^{60}$ According to the above-mentioned changes, only an individual or natural person can qualify as a labour broker for purposes of employee's tax. ${ }^{61}$ An entity will only qualify as a personal service provider if a connected person (the employee of the TES) personally provides a service to clients of the entity (TES) and any one of the following conditions applies:

1 The employee (connected person) would be regarded as an employee of the client if that person were to render service personally to the client (author's emphasis); or

5275 of 1997.

53 Van Niekerk "Personal Service Companies and the Definition of 'Employee' - Some Thoughts on Denel (Pty) Ltd v Gerber" 200526 ILJ 1908.

54 S 82 of the Employment Equity Act 55 of 1998. The High Court has intervened to end the exploitation of the employee as the weaker bargaining party and to uphold the true character of the employment relationship, albeit an unconscionable contract, to suit the needs of the stronger parties (the TES and the client). See Motor Industry Bargaining Council v Mac-Rites Panelbeaters \& Spraypainters (Pty) Ltd 200122 ILJ 1077 (N).

Revenue Laws Amendment Act 60 of 2008.

5658 of 1962.

57 S 66(1) of Act 60 of 2008 introduced a definition of a "personal service provider". The definition of a "labour broker" is limited to natural persons.

58 Ibid.

59 Wellsted 2009 Business Day 2. Andrew Wellsted is an associate at Deneys Reitz Tax.

60 Ibid.

61 lbid. 
2 the employee of the TES provides the service at the premises of the client, under the supervision and control of the client (author's emphasis); or

3 if more than $80 \%$ of the income of the TES (entity) is likely to be derived from that one client during the year of assessment. ${ }^{62}$

\section{THE ROLE OF THE INTERNATIONAL LABOUR ORGANISATION IN THE TRIPARTITE EMPLOY- MENT RELATIONSHIP}

The Constitutional Court has on several occasions referred to the ILO instruments in reaching a decision on labour matters. ${ }^{63}$ The ILO has been setting labour standards since 1919 and has as its core function the protection of workers against exploitation in the informal economy, not to be treated as "a commodity". ${ }^{64}$ In this regard the TES has been viewed with scepticism as it has been used as a mechanism to avoid statutory obligations and compliance with minimum labour standards. ${ }^{65}$ However, due to recent changes in the global market, South Africa and the ILO have been accepting the valid role of the TESs to reduce unemployment. ${ }^{66}$ The following summary attempts to highlight the ILO conventions relating to the protection of workers employed within the scope of informal employment, including workers engaged in a fixed-term employment agreement within the tripartite employment relationship:

1 Convention 87 of 1948 - concerns freedom of association and protection of the right to organise and "guarantees the right of workers and employers without distinction" to include workers outside the scope of the traditional contract of employment. ${ }^{67}$ This convention has been ratified and is therefore binding on South Africa as a member state of the ILO; ${ }^{68}$

2 Convention 98 of 1949 - the right to organise, and collective bargaining. This convention applied to all "workers";

3 Convention 100 of 1951 - promotes equal remuneration for men and women workers for work of equal value;

4 Convention 11 of 1958 - on discrimination (employment and occupation) applicable to all workers;

2 Ibid

63 See NUMSA v Bader Bop (Pty) Ltd 200324 ILJ 305 (CC); [2003] 2 BLLR 103 (CC); NEHAWU v UCT [2003] 5 BLLR 409 (CC).

64 Theron 200526 ILJ 618; Theron 200829 ILJ 15,16; and Hutchinson and Le Roux 20009 CLL 52.

65 Hutchinson and Le Roux 20009 CLL 53.

66 Benjamin 200829 ILJ 1579 states that more than 30\% of working South Africans are presently employed in the informal sector.

67 Benjamin 200829 ILJ 15791581.

$68 \mathrm{~S} 23$ of the Constitution. 
5 Convention 181 of 1997 - the Private Employment Agencies Convention, abandoned in 1998 (due to "employers" opposition) for "the first time in its long history that the ILO's standard generating machinery had failed". 69

\section{Recommendations regarding Convention 181}

- It acknowledged the existence of agencies.

- Control over agencies in the form of a system of registration or licensing by national governments.

- It proposed measures to be taken by a member state to address certain consequences relating to the responsibilities of private employment agencies protecting the following rights of workers - freedom of association, minimum wages and access to training and collective bargaining. ${ }^{70}$

- Employment security and termination of employment was not considered. ${ }^{71}$

\section{Recommendation 198 - Employment Relationship Recommendation (adopted on 15 June 2006)}

The ILO recently adopted a recommendation which aims at addressing the uncertainty regarding the employment status of workers as employees, where contractual relationships hide the true legal status and deprive these vulnerable workers of the protection due to them. ${ }^{72}$ The existence of the employment relationship should primarily be guided by the facts related to the working relationship, rather than by the agreement between the parties. ${ }^{73}$ In addition the recommendation aims to protect workers involved in multiparty contractual arrangements by requiring a set of standards to be implemented to protect the workers' rights and to include measures to indicate those responsible for the application thereof. ${ }^{74}$

These arrangements and proposals are of immense value to the current debate in South Africa regarding the banning of labour brokers or TESs, who are branded as the underclass in the employment sector because of the exploitation of workers and their labour rights.

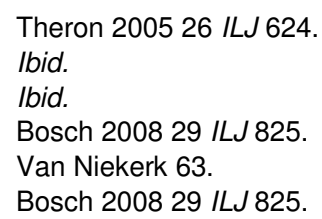




\section{THE EMPLOYMENT RELATIONSHIP AS A LEGAL FICTION WITH REFERENCE TO LAD BROKERS (PTY) LTD V MANDLA ${ }^{75}$}

This case illustrates the difficulty of identifying the correct employer in the case of an alleged unfair dismissal involving a TES. It also reflects the harsh consequences of a cancellation of the client's contract with the TES which results in a dismissal by the TES of the worker. ${ }^{76}$ The question pertaining to liability comes to the fore with emphasis on section 198 of the LRA regulating the position of the TES, the client and the worker.

The client recruited Mandla (M) and they agreed to the terms of "their employment" as stated in the case summary. ${ }^{77}$ The client then requested $\mathrm{LAD}$, a specialist labour broker, to facilitate "their employment". ${ }^{78}$ The labour broker became part of the tripartite relationship after $M$ commenced service at the client. LAD Brokers gave M a contract titled "Independent Contractor Contracting agreement" ${ }^{\prime 79}$ and after he signed it LAD entered into an agreement with the client in terms of which services would be "let" from LAD. The client paid the TES and the TES paid M in return. ${ }^{80}$

After a year the client terminated the "independent contracting agreement" with $\mathrm{M}$, the "employee" of the TES and not the agreement with the client if any. Although the Labour Court held that $\mathrm{M}$ was indeed an employee of the TES based on the contract between them, the TES contended that $M$ was an independent contractor because $\mathrm{M}$ "had at all times been in the employ of the foreign company" (client). ${ }^{81}$ The court erred in this regard and based its finding on the control test, as inferred from the wording of the contract with regard to the TES's right to terminate the agreement between the parties. ${ }^{82}$

The contents of the agreement between the client and the independent contractor reflected the following:

1 The worker was an independent contractor and no employment relationship existed between $M$ and the TEX - defying the provisions of section 198(2);

75 [2001] 9 BLLR 993 (LAC).

76 Theron 200526 ILJ 624 635. According to Theron, 61\% of cases analysed in the Services SETA study reflected the arbitrators' dismissal of the application because the applicant failed to establish an employment relationship or a dismissal in accordance with the provisions of the LRA.

77 LAD Brokers (Pty) Ltd v Mandla supra 993.

78 Ibid; s 198(2) provides that an employee is a person whose services is provided to a client by a TES. There is no agreement between the client and that person - only between the client and the TES.

79 According to s 198(3) such a worker is excluded as an employee of a TES; s 213 excludes an independent contractor from the protection of the LRA.

80 LAD Brokers(Pty) Ltd v Mandla supra.

81 Ibid.

82994. 
$2 M$ was specifically excluded from the benefits applicable to permanent employees;

3 LAD would only have supervision over certain areas of M's activities;

4 any overtime remuneration would be agreed upon the terms of the client only;

5 LAD never registered $M$ for unemployment insurance benefit or tax.

The court used the dominant impression test and the supervision and control test to establish "a unique and sui generis tripartite relationship". The judgment concluded that the person provided by the TES renders service to the client and not to the TES, despite being remunerated by the TES. ${ }^{83}$ "It is accordingly a fiction that the person concerned $(\mathrm{M})$, renders services to the TES even if it is the employer of the person (the TES) whose services are provided to the client, through the TES." ${ }^{\text {"4 }}$ The court found that the relationship between the client and $\mathrm{M}$ was that of an employment agreement as contained in section 213 of the LRA based on the placing of his personal services at the disposal of the client. ${ }^{85}$

The crux of the judgment is contained in the following statement: "It is our duty to have regard to the realities of the relationships and not to the label chosen by the parties." 86

The question is how to address the awkward situation faced by a worker who renders his services or performs work to one person, but receives remuneration from another, while both parties deny being the employer of that person. The legislator clearly intended the TES to be the employer as the court concluded in this case. The dismissal was held to be both substantially and procedurally unfair. ${ }^{87}$

\section{CONCLUSION AND RECOMMENDATIONS}

The wording of section 198(2) with regard to the definition of an employee (in terms of section 213 of the LRA) is the starting point to clear any confusion. The broad interpretation of the LRA regarding the concept "employee"; should be adhered to in respect of the "employee" of a TES. Atypical employment, specifically part-time work, is playing an increasingly important role in industrialised countries. ${ }^{88}$ Even former employees whose services were terminated should be regarded as employees in accordance with case law. ${ }^{89}$ Section 198 clearly states that "a person whose services have been procured or provided to a client by a [TES] is the employee of that [TES] and the [TES] is the employer of that person". Although section

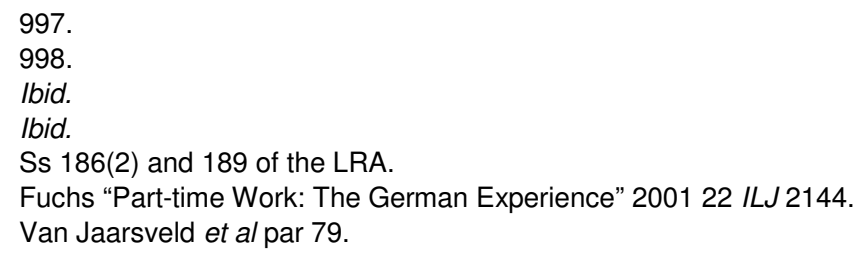


198(3) expressly excludes the independent contractor in accordance with the definition of an employee, the loophole thus created has successfully been addressed by the courts where the parties used this section to deny any liability in terms of an unfair dismissal. ${ }^{90}$ My recommendation in this respect is to afford any person who has been procured or provided to a client by a TES, the much-needed protection in accordance with our constitutional labour rights, the LRA and the ILO standards. ${ }^{91}$ The wording of section 198 should therefore be amended to give effect to our fundamental labour rights. ${ }^{92}$ The TES or the client may be regarded as the employer in accordance with the concept of the tripartite relationship.

Clauses in conflict with these underlying values, serving only the interests of the client and the TES, should be regarded as contrary to public policy. A policy of substance over form should guide the ruling of the commissioners at the CCMA. ${ }^{93}$ The dismissal of an atypical employee should be regarded as a dismissal in terms of the LRA to afford the worker as the weaker bargaining party the much-needed protection required in the circumstances, in accordance with the provisions of the LRA.

The growth in atypical labour requires urgent attention with regard to the effective protection, regulation and registration of labour brokers. ${ }^{94}$ The Metal \& Engineering Industry Bargaining Council (MEIBC) has taken the lead to protect their members in a way that regulates their involvement with atypical employment and labour brokers in particular. ${ }^{95}$ The Council prohibits general "outwork" where the employer is prohibited from undertaking work covered by non-registered parties, except in limited circumstances and prohibits the utilisation of any labour broker, unless registered with the MEIBC. A TES is furthermore required to provide proof of registration and can only be used for a limited time of 12 continuous months. The onus remains on the employer (client) to ensure that the TES complies with the MEIBC collective agreement. ${ }^{96}$

Workers in any employment relationship have the right to organise and the right to fair labour practices. Currently section 198 undermines the rights of workers as it maintains the fiction that the TES is an employer instead of the intermediary between the client and the worker. The principle of equal remuneration for equal work is not easily enforced in a system without collective bargaining and binding collective agreements which should be used as a mechanism to enforce the rights of all workers in temporary employment. ${ }^{97}$

See the judgment in the Mandla case supra.

Cheadle "Regulated Flexibility: Revisiting the LAR and the BCEA" 200627 ILJ 672.

$\mathrm{S} 23$ of the Constitution.

Bosch 200829 ILJ 825 and 839.

Cheadle 200627 ILJ 672 and 701.

Theron 200526 ILJ 627.

Ibid.

Theron 200526 ILJ 618 642. The temporary worker's profile is said to "constitute an underclass" as a worker is presented under a fixed-term contracts without equal payment and job security. 
To conclude on a positive note: Part-time work is regarded as an important instrument in reducing unemployment and maintaining contact with the world of employment. ${ }^{98}$ It could also provide opportunities to improve labour skills and to involve people with professional skills who prefer or need the flexibility of a part-time position. The challenges related to the exploitation of workers' rights should, however, be addressed by legislation in order to make flexibility work for the needs of workers, labour brokers and the clients. The ultimate goal should be to ensure fairness in balancing the interests of parties within the tripartite employment relationship and to enforce the rights of workers.

98 Fuchs 200122 ILJ 2146. 